\title{
PENGUATAN BIDANG MARKETING DALAM UPAYA MENINGKATKAN VOLUME PENJUALAN PADA KUBAH KONVEKSI DENGAN PELATIHAN BISNIS ONLINE
}

\section{STRENGTHENING OF MARKETING IN THE EFFORT TO INCREASE THE SALES VOLUME OF KUBAH KONVEKSI THROUGH ONLINE BUSINESS TRAINING}

\author{
P Harissa 1a, M Anggrahini1 \\ ${ }^{1}$ Lembaga pengabdian pada masyarakat Universitas Lenglangbuana, Bandung. \\ aKorespondensi:Muliastuti Anggrahini ; E-mail: Muliaastuti2909@gmail.com
} (Diterima: 15-02-2020; Ditelaah: 16-02-2020; Disetujui: 02-10-2020)

\begin{abstract}
Although it has been proven during the economic crisis, the Small and Medium Enterprises (SMEs) still require a transfer of knowledge in relation to their business development. One of the necessary knowledge is about the effective marketing method. The development of technology can be used as a marketing media so the SMEs can compete as well. This community service and partnership program is intended to provide knowledge and skills for Kubah Konveksi management in the online business utilization for sales and to catch greater business opportunities. The activity methods used are lecture, discussion and accompaniment based on the initial evaluation as the basis to determine the target group's knowledge position on the online business. The result demonstrates the raise of training participants' awareness on the utilization of online business to increase their business income. This is shown by the participants' enthusiasm in applying the training outcome and to continue the activity after the end of the program.

Keywords: Online business, Marketing, SME.
\end{abstract}

\begin{abstract}
ABSTRAK
Walaupun telah teruji saat terjadi krisis ekonomi, UMKM masih membutuhkan transfer pengetahuan terkait pengembangan usahanya. Salah satu pengetahuan yang dibutuhkan adalah mengenai metode pemasaran yang efektif. Perkembangan teknologi dapat dimanfaatkan sebagai media pemasaran, sehingga UMKM dapat turut bersaing. Program pengabdian dan kemitraan masyarakat ini bertujuan memberikan pengetahuan dan ketrampilan kepada para pengurus Kubah Konveksi dalam hal pemanfaatan bisnis online dalam penjualan dan menangkap peluang bisnis yang lebih luas. Metode kegiatan yang dilakukan adalah metode ceramah, diskusi dan pendampingan yang didasari oleh evaluasi awal sebagai landasan untuk menentukan posisi pengetahuan kelompok sasaran mengenai bisnis online. Hasil pelaksanaan menunjukkan adanya peningkatan kesadaran peserta pelatihan terkait pemanfaatan bisnis online untuk meningkatkan pendapatan usahanya. Hal ini terlihat dari antusias para peserta untuk mengaplikasikan hasil pelatihannya dan melanjutkan kegiatan tersebut setelah selesai programnya.

Kata kunci: Bisnis online, marketing, UMKM.
\end{abstract}

Harissa, P., Anggrahini, M. (2020).Penguatan Bidang Marketing Dalam Upaya MEningkatkan Volume Pengajuan Pada Kubah Konveksi Dengan Pelatihan Bisnis Online. Jurnal Qardhul Hasan : Media Pengabdian kepada Masyarakat, 6(2), 101-106. 


\section{PENDAHULUAN}

Target pasar bisnis konveksi dapat dikatakan tidak terbatas. Mulai dari pemesanan satuan hingga pemesanan massal seperti seragam perusahaan, seragam untuk acara-acara tertentu, dan lain-lain. Selain itu dapat juga dengan bekerjasama dengan pelaku bisnis distro dengan memberikan suplai produk.

Salah satu yang meramaikan persaingan usaha konveksi di Kota Bandung adalah Kubah Konveksi yang dimiliki oleh Pondok Pesantren Hidayatullah Bandung. Usaha ini dijalankan oleh beberapa pengurus pondok. Produk dari Kubah Konveksi adalah berbagai jenis pakaian seperti $t$-shirt, sweater, jumper, kemeja, kostum olahraga, jaket, bahkan seragam almamater. Bahan baku yang digunakan adalah jenis kain cotton carded yang memiliki spesifikasi ketebalan 20s, 24s dan 30s, fleece, ripstok, drill, lacoste, combed, dan lain-lain. Usaha ini berdiri pada bulan September 2018, namun pada bulan Desember 2018 sampai dengan bulan April 2019 tidak berproduksi karena jumlah pemesanan terlalu sedikit sehingga tidak mampu menutup biaya produksi.

Persaingan usaha konveksi yang terus berkembang menuntut Kubah Konveksi untuk selalu menghasilkan produk berkualitas dan sesuai dengan permintaan pasar. Selama ini pesanan pada Kubah Konveksi baru datang dari luar pulau Jawa karena para pengurus pernah bertugas di daerah-daerah tersebut. Pesanan-pesanan tersebut hanya berasal dari relasi para pengurus tersebut dan masih sangat sedikit. Dalam rangka meningkatkan jumlah pemesanan dan mempertahankan eksistensi perusahaan, Kubah Konveksi dituntut untuk melakukan langkah-langkah riil dan kiatkiat tersendiri, antara lain adalah dengan melakukan Online Marketing (Bisnis online), yaitu suatu usaha untuk mempromosikan sebuah merk dengan menggunakan media digital yang dapat menjangkau konsumen secara tepat waktu, pribadi dan relevan.

Tipe pemasaran digital mencakup banyak teknik dan praktek yang terkandung dalam kategori pemasaran internet. Seiring dengan semakin gencarnya internet marketing, maka pengetahuan dan keterampilan pemasaran/bisnis online menjadi sebuah kebutuhan yang harus dimiliki oleh setiap pelaku bisnis, termasuk pengurus Kubah Konveksi.

Bisnis online adalah kegiatan yang menggunakan fasilitas jaringan internet untuk melakukan segala kegiatan yang dapat dilakukan secara online seperti halnya bisnis, daftar kuliah, searching, stalking, mencari berita dan lain sebagainya (Kurniawan, 2013). Selain itu, bisnis online juga diartikan sebagai sebuah tempat berbagi informasi dimana para pelakunya dapat saling menyumbangkan kemampuannya dalam membentuk komunitas yang solid via internet (Jasmadi, 2008). Secara lebih praktis, bisnis online adalah kegiatan jual beli dalam sambungan internet dan fitur belanja online yang tersedia (Wicaksono, 2008).

Beberapa alasan mengapa bisnis online memiliki prospek yang menjanjikan antara lain (Rahman \& Mawardi, 2017): Tidak membutuhkan modal yang besar; Tidak membutuhkan tempat strategis; Kekurangan SDM dapat dibantu oleh orangorang terdekat; Praktis, tidak perlu bertemu konsumen secara langsung; Fleksibel, dapat mengikuti keadaan penjual.

Mempermudah belajar komunikasi yang baik.

Walaupun terdapat banyak jenis bisnis online, tetapi berdasarkan jenis produk yang dijual, hanya terdapat dua klasifikasi bisnis online, yaitu:

Bisnis online dengan produk fisik, yaitu bisnis online yang menjual barang dan produk yang dapat disentuh dan dirasakan, misalnya produk elektronik, pakaian, makanan, dan lain-lain. Produk Kubah Konveksi termasuk dalam kategori ini.

Bisnis online dengan produk digital, yaitu bisnis online yang memperjualbelikan produk yang secara fisik tidak dapat disentuh, tetapi dapat dirasakan manfaatnya. 


\section{MATERI DAN METODE}

Metode yang digunakan dalam PKM ini adalah presentasi dan implementasi materi, diikuti pelatihan secara langsung dan bertahap kepada peserta. Media yang digunakan adalah laptop dan proyektor untuk menampilkan slide presentasi. Tujuan dari pelaksanaan Pengabdian Kepada Masyarakat (PKM) ini adalah:

Untuk memberikan pengetahuan mengenai perkembangan internet dan berbagai peluang bisnis baru akibat dari kemajuan internet. Untuk memberikan kesempatan bagi para santri dalam rangka mengaplikasikan ilmu yang diberikan.

Untuk memberikan pengetahuan kepada pengurus Kubah Konveksi mengenai online marketing, manajemen pemasaran usaha kecil dan menengah, dan kewirausahaan.

Rancangan pelaksanaan kegiatan pengabdian kepada masyarakat (PKM) ini adalah sebagai berikut:

Memberikan pelatihan mengenai perkembangan internet dan peluang bisnis baru dari kemajuan internet.

Memberikan pelatihan mengenai tatacara pemasaran melalui internet di Facebook, Shopee, Google, maupun marketplace lainnya.

Memberikan pelatihan kepada pengurus kubah konveksi mengenai online marketing, manajemen pemasaran usaha kecil dan menengah, dan kewirausahaan.

\section{Tahap Diskusi Anggota dan Pendampingan}

Tahap awal dari pelatihan ini adalah mendata segala kebutuhan program pelatihan dan melihat apa saja yang sudah dihasilkan mitra.

\section{Tahap Pelaksanaan}

Tahap pelaksanaan adalah tahapan bagaimana kita memberikan pelatihan kepada para pengurus Kubah Konveksi, para santri, dan ibu-ibu di sekitar Pondok Pesantren Hidayatullah. Pelatihan yang diberikan bersifat pelatihan dasar dan spesifik.

\section{Tahap Evaluasi}

Tahap evaluasi dilakukan setelah pelatihan berlangsung guna melihat kekurangan dan kendala yang timbul setelah adanya pelatihan tersebut. Tujuan dari diadakannya tahap ini adalah untuk mengamati serta menganalisis keberhasilan program ini. Hasilnya akan dijadikan dasar dalam pembuatan laporan Pengabdian Kepada Masyarakat.

\section{Tahap Pembuatan Laporan}

Tahap terakhir yang dilakukan adalah tahap pembuatan laporan. Tahap ini dilakukan untuk menyusun semua data yang telah didapat selama kegiatan berlangsung agar diperoleh hasil yang terbaik.

Luaran dari kegiatan ini adalah pengurus Kubah Konveksi mampu memanfaatkan internet dan media digital efektivitas dan efisien strategi pemasaran sehingga mampu menghadapi persaingan di pasar global.

\section{HASIL DAN PEMBAHASAN}

Pelaksanaan Kegiatan Pengabdian Kepada Masyarakat (PKM) diawali dengan Focus Group Discussion (FGD) yang melibatkan semua anggota tim dan tenaga lapangan. FGD bertujuan untuk merumuskan konsep dan teknis kegiatan, sehingga pada pelaksanaan kegiatan pelatihan online marketing nantinya berjalan dengan efisien dan minim kendala. Pelaksanaan FGD dilakukan pada tanggal 28 September 2019 dan didapatkan bahwa seluruh anggota tim mampu menyamakan persepsi dan dapat diambil langkah strategis untuk pelaksanaan pelatihan.

Kegiatan Pengabdian Kepada Masyarakat (PKM) ini dilaksanakan pada 5 Oktober 2019, pukul 09.00 sampai dengan 15.00 WIB di Pondok Pesantren Hidayatullah yang terletak di Jl. R. Endang Suwanda no. 18 A, Pasirleutik, Kelurahan Padasuka, Kecamatan Cimenyan Kabupaten Bandung. Sasaran program ini adalah pengurus Kubah 
Konveksi, para santri, dan ibu-ibu di sekitar Pondok Pesantren Hidayatullah. Untuk menunjang pelatihan kami memberikan panduan berupa modul pelatihan penjualan online. Adapun fasilitas lainnya yang kami berikan adalah sarana hotspot. Peserta diharuskan membawa smartphone dengan koneksi internet untuk proses implementasi materi presentasi. Jumlah peserta yang hadir dalam pelatihan tersebut adalah 26 orang.

Materi pertama yang diberikan dalam pelatihan adalah pengenalan bisnis online. Pemilihan materi didasarkan pada data bahwa pengguna internet terbesar keenam di dunia adalah Indonesia (Ramadhan, 2018), sehingga pengguna internet tersebut dapat menjadi target pemasaran produk ataupun jasa melalui metode online marketing yang baik. Materi ini menjelaskan mengenai langkah-langkah dan tips memulai bisnis online, serta berbagai metode online marketing yang tersedia saat ini. Peserta juga diberi kesempatan mengajukan contoh-contoh bisnis online yang dapat dimulai setelah pelatihan. Peserta juga diberikan motivasi berwirausaha untuk memperkuat jiwa kewirausahaan dan kreativitas para peserta. Hal ini berguna untuk mendorong peserta mampu mempersiapkan roadmap jangka panjang pada bisnis online yang akan dijalankan.

Materi kedua dalam pelatihan ini adalah mengenai tips-tips sukses bisnis melalui marketplace. Dalam materi ini dijelaskan mengenai definisi marketplace, cara kerja, serta cara bergabung dan meningkatkan traffic pada online-marketplace tertentu. Boris Wertz dan Angela Tran Kingyens (2013) mendefinisikan online-marketplace sebagai situs jual-beli yang menghubungkan penyedia produk atau jasa (penjual) dengan mereka yang mencari untuk membeli produk atau layanan (pembeli), sehingga tercipta efisiensi pasar. Adipranata, dkk (2013) juga menyatakan bahwa marketplace dianggap bisa memberikan keuntungan bagi seluruh pihak, terutama pengusaha pemula. Pada tahap ini para peserta sudah diminta mencatat dan mempersiapkan kelengkapan yang dibutuhkan untuk memulai bisnis online, seperti ide usaha, produk/jasa yang akan dijual, alamat email, termasuk nama usaha yang akan digunakan.

Gambar 1. Penyampaian Materi

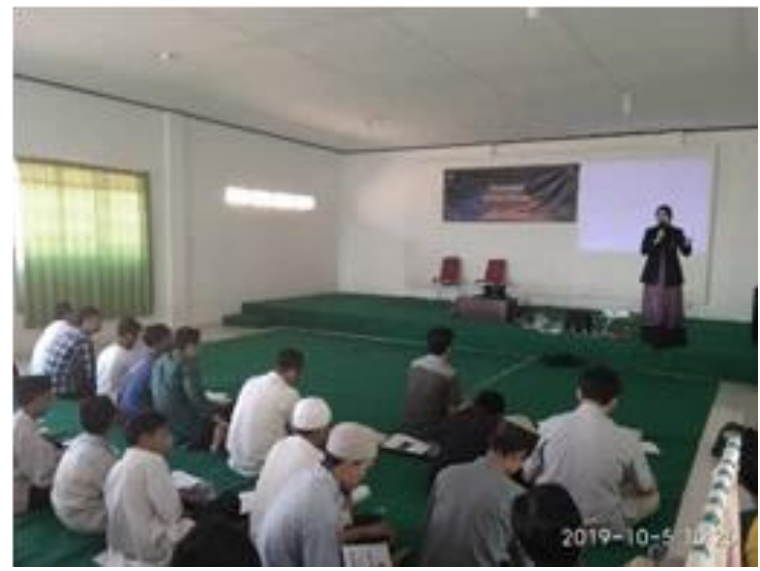

Materi ketiga dalam pelatihan ini adalah pemanfaatan media sosial dalam online marketing. Moriansyah (2015) menyatakan bahwa pemasar yang aktif promosi menggunakan media sosial dapat menstimulus pengguna lainnya untuk menjadi aktif shopping. Oleh karena itu, pemasaran melalui medis sosial merupakan sebuah kegiatan yang diperlukan dalam pemasaran. Dalam materi diberikan trik dan tips dalam pemnafaatan iklan di Facebook (Facebook Ad), mengingat hingga saat ini platform ini merupakan yang terbanyak digunakan oleh masyarakat Indonesia. Gambar 2. Penyampaian Materi

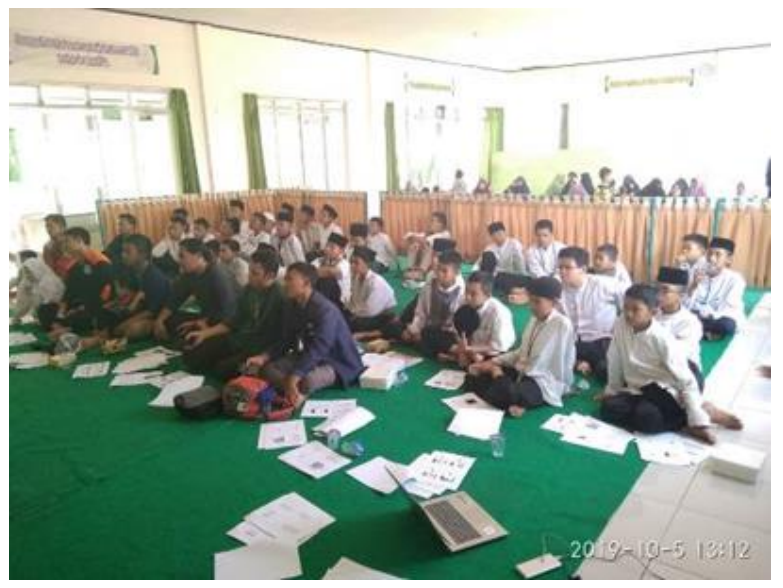


Materi terakhir yang diajarkan adalah mengenai manajemen pemasaran usaha kecil. Manajemen pemasaran diperlukan karena keberhasilan seorang pemasar terletak pada kemampuan untuk menciptakan pelanggan dan mempertahankannya sebagai mitra seumur hidup atau membuat pelanggan tetap loyal pada pemasar dan mereknya (Dharmmesta, 2003). Peserta juga diberikan pengetahuan mengenai tiga pilar dasar strategi pemasaran modern, yaitu segmenting (segmentasi pasar), targeting (penetapan sasaran pasar), dan positioning (penetapan posisi pasar) (Kotler, 1995). Segmenting dapat didefinisikan sebagai pembagian pasar menjadi kelompok-kelompok pembeli yang menyebabkan mereka membeli produk yang sama. Targeting merupakan kegiatan mengevaluasi keaktifan daya tarik setiap segmen pasar dan memilih salah satu atau lebih dari segmen pasar tersebut untuk dimasuki. Sedangkan positioning adalah tindakan untuk menempatkan posisi bersaing produk dan bauran pemasaran yang tepat pada setiap pasar sasaran. Keterkaitan ketiga pilar tersebut dalam proses pemasaran produk akan menentukan hasil penjualan produk tersebut dalam kurun waktu tertentu. Pada pelatihan ini, para peserta dilibatkan dalam proses analisis sederhana terhadap segmensegmen pemasaran dalam bisnis online sehingga dapat menentukan target pasar yang akan mereka masuki serta menentukan tindakan yang harus dilakukan dalam pemasaran produk secara online.

\section{Monitoring dan Evaluasi}

Monitoring merupakan suatu proses pengawasan untuk melihat perkembangan proses yang direncanakan apakah sesuai dengan prosedur yang sudah ditetapkan atau tidak. Hal ini penting mengingat transfer teknologi dari pengusung ke mitra tidak bisa dilakukan dalam waktu singkat. Sementara itu evaluasi merupakan suatu proses untuk melihat ketercapaian program apakah sesuai dengan tujuan awal program. Dari hasil monitoring dan evaluasi terlihat bahwa prosedur sudah diterapkan dalam praktek mitra pasca pelatihan.

Tabel 1. Perbandingan sebelum dan setelah pelaksanaan program

\begin{tabular}{|c|c|c|c|}
\hline \multicolumn{2}{|c|}{$\begin{array}{l}\text { Sebelum } \\
\text { pelaksanaan PKM } \\
\text { dan sudah membuka } \\
\text { toko online/offline }\end{array}$} & \multicolumn{2}{|c|}{$\begin{array}{l}\text { Setelah pelaksanaan } \\
\text { PKM }\end{array}$} \\
\hline Nama & $\begin{array}{l}\text { Bidang } \\
\text { Usaha }\end{array}$ & Nama & $\begin{array}{l}\text { Bidang } \\
\text { Usaha }\end{array}$ \\
\hline $\begin{array}{l}\text { Abdul } \\
\text { Wakit }\end{array}$ & Konveksi & $\begin{array}{l}\text { Abdul } \\
\text { Wakit }\end{array}$ & Konveksi \\
\hline Aditya & Herbal & Aditya & Herbal \\
\hline Setiadi & HNI & Setiadi & HNI \\
\hline Suhendar & $\begin{array}{l}\text { Herbal } \\
\text { HNI }\end{array}$ & Suhendar & $\begin{array}{l}\text { Herbal } \\
\text { HNI }\end{array}$ \\
\hline Muhsin & Konveksi & Muhsin & Konveksi \\
\hline Naufal AB & $\begin{array}{l}\text { Konveksi } \\
\text { dan } \\
\text { Perlengk } \\
\text { apan } \\
\text { Militer }\end{array}$ & Naufal AB & $\begin{array}{l}\text { Konveksi } \\
\text { dan } \\
\text { Perlengk } \\
\text { apan } \\
\text { Militer }\end{array}$ \\
\hline Amin & $\begin{array}{l}\text { Herbal } \\
\text { HNI }\end{array}$ & Amin & $\begin{array}{l}\text { Herbal } \\
\text { HNI }\end{array}$ \\
\hline Hanifah & $\begin{array}{l}\text { Pakaian } \\
\text { Muslim } \\
\text { Anak }\end{array}$ & Hanifah & $\begin{array}{l}\text { Pakaian } \\
\text { Muslim } \\
\text { Anak }\end{array}$ \\
\hline Fitri Ani & $\begin{array}{l}\text { Herbal } \\
\text { HNI }\end{array}$ & Fitri Ani & $\begin{array}{l}\text { Herbal } \\
\text { HNI }\end{array}$ \\
\hline & & $\begin{array}{l}\text { Yusep } \\
\text { Suhendar } \\
\text { Ramadhan } \\
\text { Bustanul } \\
\text { Arifin } \\
\text { Asep } \\
\text { Juhana }\end{array}$ & $\begin{array}{l}\text { Madu } \\
\text { Herbal } \\
\text { HNI } \\
\text { Sayur } \\
\text { Organik }\end{array}$ \\
\hline
\end{tabular}

Gambar 3. Pendampingan Mitra

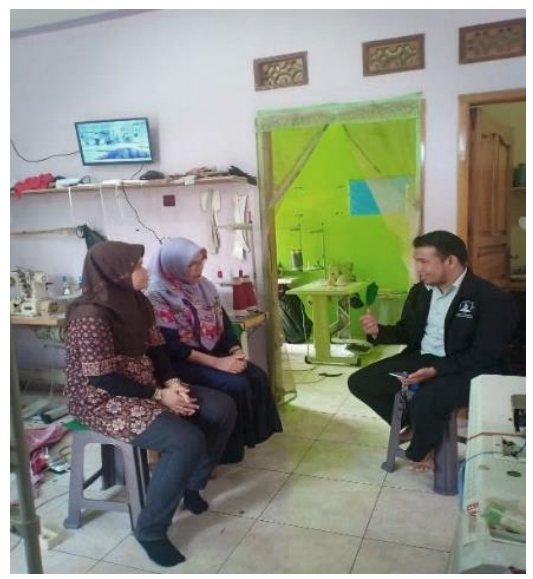




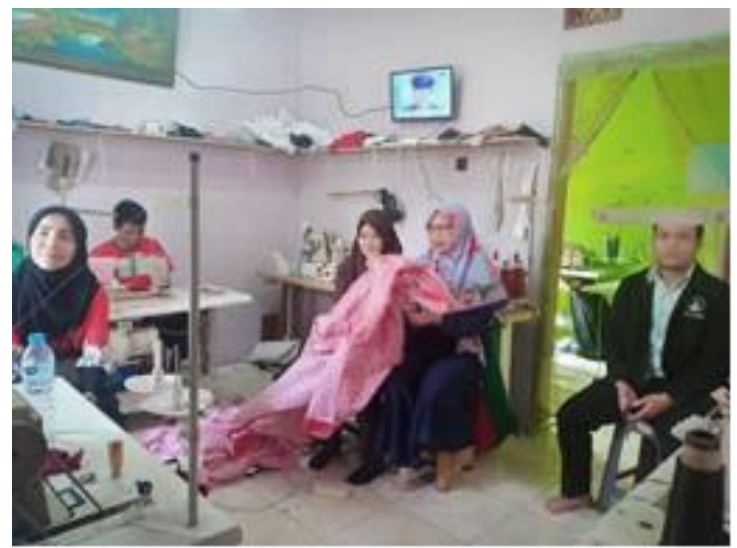

Gambar 4. Pendampingan Mitra.

\section{KESIMPULAN}

Berdasarkan program yang telah dilaksanakan diperoleh kesimpulan bahwa kegiatan penyuluhan dan praktik pelatihan kepada mitra melalui program ini telah tercapai. Hal ini terlihat pada saat postpelatihan, dimana ditemukan bahwa mitra telah dapat menerapkan dan memanfaatkan pengetahuan dan keterampilan tersebut, walaupun efek kuantitatifnya belum dapat diukur. Kegiatan ini sebaiknya dapat dilakukan di daerah lain dalam rangka pemberdayaan masyarakat berbasis ilmu dan teknologi.

\section{UCAPAN TERIMAKASIH}

Ucapan terima kasih yang setinggitingginya disampaikan kepada Lembaga Pengabdian Pada Masyarakat Universitas Langlangbuana Bandung, Dekan Fakultas Ekonomi Universitas Langlangbuana Bandung dan seluruh jajarannya, serta seluruh pimpinan Universitas Langlangbuana Bandung atas dukungan materiil dan moril dalam pelaksanaan kegiatan ini. Ucapan terimakasih juga dihaturkan kepada mitra kegiatan PKM ini, dalam hal ini Kubah Konveksi, para pengurus Pondok Pesantren Hidayatullah Bandung, serta seluruh pihak yang telah mendukung pelaksanaan kegiatan ini.

\section{DAFTAR PUSTAKA}

Fadiati, A. 2011. Menjadi Wirausaha Sukses: Rosda

Jasmadi. 2008. Membangun Komunitas Online secara Praktis dan Gratis. Jakarta: E-Media Solusinso.

Kotler, Philip. 1995. Marketing Jilid II. Jakarta: Erlangga.

Kurniawan, Dedik. 2013. Kupas Tuntas Bisnis \& Penghasila Online. Jakarta: Elex Media Komputindo.

Muhammad Anwar H.M. 2014. Pengantar Kewirausahaan Teori dan Aplikasi. Kencana

Mulyadi, 2010. Kewirausaan dan Manajemen Usaha Kecil: Alfabeta

Rahman, Fadhlir \& Mawardi, M. Kholid. 2017. Strategi Umkm dalam Membangun Brand Toko Online di Marketplace (Studi pada komunitas Tokopedia di Kota Bekasi). Jurnal Administrasi Bisnis (JAB), Vol. 53 No. 1, Desember 2017. Hal 39-48.

Ramadhan, Bagus. 2018. Inilah perkembangan digital indonesia tahun 2018. Diakses 21 Januari 2020 dari https://www.goodnewsfromindonesia .id/2018/02/06/inilah-

perkembangan-digital-indonesiatahun-2018.

Sudrajat, SE. 2011, Kiat Mengentaskan Pengangguran Melalui Wirausaha: Bumi Aksara

Suryana, 2013. Kewirausahaan (Kiat dan Proses Menuju Sukses): Gudang Penerbit

Suryana. 2003. Kewirausahaan. Pedoman Praktis, Kilat dan Proses Menuju Sukses. Jakarta : PT Salemba Empat

Uma Sekaran. 2013. Metodologi Penelitian Untuk Bisnis. Jakarta: Salemba Empat

Wertz, B. \& Kingyens, A. T. 2013. A Guide to MARKETPLACES. Versionone. Diakses pada 21 Januari 2020, dari www.versionone.vc.

Wicaksono, Y. 2008. Membangun Bisnis Online dengan Mambo. Jakarta: Elex Medisa Komputindo. 